\title{
Appendiceal Carcinoma Pathologic Primary Tumor TNM Finding v7
}

National Cancer Institute

\section{Source}

National Cancer Institute. Appendiceal Carcinoma Pathologic Primary Tumor TNM

Finding v7. NCI Thesaurus. Code C89894.

A pathologic finding about one or more characteristics of appendiceal carcinoma,

following the rules of the TNM AJCC V7 classification system as they pertain to staging of the primary tumor. 